\title{
Vital Tooth
}

National Cancer Institute

\section{Source}

National Cancer Institute. Vital Tooth. NCI Thesaurus. Code C52669.

A tooth with functioning pulpal tissue. 